\title{
The 2017 Myall Creek Massacre Commemoration Speech
}

\author{
Mark Tedeschi AM QC
}

The Myall Creek massacre on 10 June 1838, that resulted in the horrific murder of 28 men, women and children of the Weraerai tribe of the Kamilaroi nation, has come to represent the multitude of massacres of Indigenous people that occurred all over Australia during a period of more than 120 years. This is because we know more today about the murders at Myall Creek than any of the hundreds of other massacres. We know so much today about this one largely because of the investigation and two trials of the perpetrators conducted in 1838.

The man who successfully prosecuted the two trials of those responsible for the massacre was the then Attorney-General of New South Wales, John Hubert Plunkett. It was, in my view, the greatest challenge of his long career and one of his greatest achievements. Unusually for the times, two trials arose from the massacre, and both provoked enormous controversy and hostility throughout the colony towards the prosecutor. The powerful forces of the landowning settlers were pitted against Plunkett and caused him endless difficulties. Plunkett's approach to these prosecutions was innovative and bold in equal measure. He faced massive difficulties in overcoming bigotry and vested interests. Despite the fact that there had been an eyewitness to the massacre-the Indigenous stationhand Yintayintin (known as Davy) - the law at that time prevented

\section{How to cite this book chapter:}

Tedeschi, M, AM QC. 2020. The 2017 Myall Creek Massacre Commemoration Speech. In: Marczak, N. and Shields, K. (eds.) Genocide Perspectives VI: The Process and the Personal Cost of Genocide. Pp. 155-158. Sydney: UTS ePRESS. DOI: https://doi .org/10.5130/aaf.i. License: CC BY-NC-ND. 
any Aboriginal person from giving evidence in court. Plunkett spent the next 20 years trying to remedy this deficiency-without success. New South Wales was, in fact, one of the last jurisdictions in Australia to allow Aboriginal people to give evidence in court.

It is instructive to look closely at the long-term effects of the 1838 Myall Creek murder trials. They marked one of the few times in the history of Aboriginal displacement that Europeans were punished for the murder of Aboriginal Australians. Those trials stand as an early statement of principle that Australian courts had at least the capacity to operate without fear or favour and to treat all people, including those on the margins of white society, equally. That is not to say that the law always operated in this way, or even that it frequently did during the colonial period; but on the occasion of the Myall Creek murder trials it certainly did. Plunkett's advocacy and tactics at the second trial succeeded in persuading a jury of 12 white, free men to convict seven white defendants for the brutal slaying of an Aboriginal child, who represented the 28 members of that infant's kinship group that had been murdered. That Plunkett was able to do this in the face of almost universal hostility to the prosecution was nothing short of miraculous. It would never happen again during the colonial period, or even after the federation of the Australian States in 1901.

Tribute should also be paid to others who did the right thing in 1838: George Anderson, the convict hut keeper on Myall Creek Station, who attempted to convince the perpetrators not to commit the atrocity, and who later bravely gave evidence against them. Yintayintin (Davy) was the Aboriginal station worker on Myall Creek Station who at great risk to himself followed the perpetrators at a distance while hidden in the bush and personally witnessed the murders, so that he could report back to George Anderson. William Hobbs was the station manager on Myall Creek Station who was so repulsed by what had happened in his absence that he reported the atrocity in writing to the Governor, and in retaliation was then sacked by his employer, landowner Henry Dangar. Police Magistrate Captain Edward Denny Day conducted an exemplary investigation of the incident and managed to arrest and charge 11 of the 12 perpetrators, and then to bring them to Sydney for trial. The trial judge at the second trial, Justice William Westbrooke Burton, reinforced to the jury the sanctity of all life and set the tone for a fair hearing. And the 12 white jurors in the second trial who were brave enough to convict the seven defendants in the face of extreme public hostility; and especially juror William Knight, who spoke up to correct the initial, incorrect verdict of acquittal, so that convictions were eventually recorded.

There is no doubt that the trials failed to stop the attempts to annihilate Aboriginal people. The hanging of seven of the Myall Creek murderers merely served to drive future perpetrators underground, so that more surreptitious means, such as poisonings, were used instead of brutal, bloody slayings by sword or bullet, or herding over cliffs or into swamps. However, one cannot assess the significance of the Myall Creek murder trials merely by that measure, 
just as one cannot assess the success of the Nuremberg trials in Europe after the Second World War by the number of genocides that have since taken place in various parts of the world.

In my view, the two trials in 1838 were more akin to modern-day war crimes trials than to domestic murder trials, even though the concept of war crimes lay more than 100 years in the future. There was undoubtedly an ongoing, internal, frontier war at the time, albeit quite one sided, between the white settlers and the Indigenous inhabitants, whom the former were attempting to displace and disperse. The war against the Indigenous population involved a systemic policy, often approved or acquiesced in by the white authorities, of unlawfully exterminating those Aboriginal people who stood in the way of the expansion of English settlement, or who posed a threat to the white pastoralists and their farming activities. In my view, the perpetrators of the mass murders at Myall Creek Station on 10 June 1838 were motivated by genocidal intentions and their actions were an example of what today we call 'ethnic cleansing. The fact that almost the whole tribe was decimated-including old men, women and children-demonstrated clearly the genocidal intent of the perpetrators. The subsequent sexual abuse of one female Indigenous victim, who was spared her life on the day of the massacre, but only for what must have been a few excruciating days, illustrated the objectification of the victims. Recent history has shown that sexual violence often goes hand-in-hand with genocide, and that is why systemic sexual offences against enemy populations in war zones are now categorised as war crimes.

In addition, the actions of the perpetrators can be viewed as an example of what has become known as 'collective punishment'-a form of retaliation whereby a suspected offender's family, friends, acquaintances, neighbours or an entire ethnic group is targeted for punishment, and where the punished group may have no direct association with the act that is being punished. The victims in this case had been living peacefully on Myall Creek Station for several months and had done nothing to justify their victimisation. Collective punishment has been categorised as a war crime since the 1949 Fourth Geneva Convention and genocide has been categorised as an international crime by the Genocide Convention as adopted by the United Nations General Assembly in 1948, which came into force in 1951.

By modern-day standards, the actions of the Myall Creek murderers were war crimes and part of a deliberate, state-sanctioned genocide of the Aboriginal people that today would be punishable by the rules of international criminal law. The fact that vast numbers of genocidal murders in colonial Australia went unpunished would today provide evidence of state sanction, justifying international intervention in the prosecution of the perpetrators and their national leaders. While such laws did not exist in 1838, the approach taken by John Hubert Plunkett towards the case was consistent with these legalities, and demonstrated an enlightened and visionary attitude that was unparalleled in his time, or for more than 100 years afterwards. John Plunkett did 
not just prosecute 11 men for murder. He prosecuted his entire society for its connivance in the attempted annihilation of the Aboriginal people and their culture, and that is why it aroused such prevalent hostility. His contemporaries vehemently resented him during the trial and for years afterwards. It was a testament to his perseverance and tactical skills that he convinced 12 jurors to convict seven of the perpetrators, because they were not only condemning those men to their deaths, but also stingingly rebuking their own society. So, while the 1838 trials and convictions did not prevent future massacres, they stand as a beacon of humanity and interracial justice that illuminated the way for Australia to develop as a civilised nation.

Australian schools, both primary and secondary, have always devoted much time to teaching students about the great, white explorers-people like John Oxley, Charles Sturt and Major Thomas Mitchell. Very few schools, however, teach what almost invariably happened within a few years of these explorers' discoveries: the expansion of white pastoralists into areas that had for millennia been occupied by Indigenous clans. What followed was the expropriation of their land, the destruction of their culture and society, and the massacres of tens of thousands of Indigenous peoples in hundreds of locations all over Australia.

In my opinion, the story of what happened to the Aboriginal inhabitants in colonial times should be taught in our schools as readily as we teach the exploits of the great, white explorers. The two accounts are inextricably intertwined. One almost inevitably followed the other. A real acceptance by mainstream Australia of the horrors perpetrated against our Indigenous communities in the colonial period will bring with it an understanding of the long-term trauma transferred through the generations. We readily recognise that the trauma of other genocides and crimes against humanity_-such as those during the Nazi period in Europe, in the former Yugoslavia during the 1990s, and in countries like Rwanda and Cambodia-can be deeply felt for many generations after the killings have ended. If we acknowledge that Aboriginal communities were subjected to massacres in a multitude of locations all over Australia for more than a century, there may be more sympathy for the current generations striving for equanimity, understanding and acceptance.

Until we recognise that what occurred was a war of extirpation or annihilation, until we acknowledge that what was perpetrated amounted to genocide and that today it would be categorised as a war crime, and until we teach this to all children throughout Australia, we will not reach our full maturity as a nation. 